IJCRR

Section: Healthcare ISI Impact Factor (2019-20): 1.628

IC Value (2019): 90.81 $\operatorname{SJIF}(2020)=7.893$

(c) (i) (8)

Copyright@IJCRR

\section{$\therefore$ \\ Efficacy of Unani Formulation in Cervical Ectopy (Quruhal Rahim) - An Open Observational Study}

\section{Shamim Ansari ${ }^{1}$, Wajeeha Begum², Kouser Fathima Firdose ${ }^{3}$}

\author{
'PG Scholar Department. of 1 lmul Qabalat wa Amraze Niswan, NIUM, Bengaluru - 560091, Karnataka, lndia; 2 Professor \& HOD Department of \\ 1 lmul Qabalat wa Amraze Niswan, NIUM, Bengaluru - 560091, Karnataka, India; 'Lecturer, Department of 1 lmul Qabalat wa Amraze Niswan, \\ NIUM, Bengaluru - 560091, Karnataka, lndia.
}

\title{
ABSTRACT
}

Introduction: Cervical ectopy (quruhal Rahim) is a benign and common gynaecological condition in India with $19 \%$ of the total population. About $80-85 \%$ of women suffer from Cervical Erosion. Cervical erosion is diagnosed by per speculum examination. Considering these facts methi, alsi,babuna, nakhuna, karamkalla, has been selected to evaluate the efficacy in the form of Abzan in Quruhal Rahim.

Objective: To evaluate the efficacy of Abzan in Quruhal rahim with unani formulation.

Methods: This is an open observational clinical study in clinically diagnosed woman $(n=30)$ in the age group of $18-45$ yrs having symptoms of vaginal discharge, normal or inflammatory changes in pap smear were included and patients with malignancy, Pelvic inflammatory disease, systemic illnesses \& Sexually transmitted disease, oral contraceptive Pills and Intrauterine contraceptive device, pregnancy and lactation were excluded. Joshanda of methi $5 \mathrm{gms}$, alsi $5 \mathrm{gms}$, babuna $3 \mathrm{gms}$, nakhuna $5 \mathrm{gms}$, karmkalla 10 gms in 2 litres of warm water. After menses use daily one time for sitz bath for 15 minuts for 21 days. The primary and secondary outcome was assessed. Cervical ectopy by arbitrary grading scale and SF-12 for Quality of life were health-related quality of the life is measured by SF-12 Questionnaire. To provide easily interpretable scales for physical and mental health.

Results: Vaginal discharge mean score before and after treatment is $2.37 \pm 0.57$ and $0.367 \pm 0.49$ respectively with $p<0.0001$. In cervical erosion, grading means score before and after treatment is $1.7 \pm 0.65$ and $0.47 \pm 0.58$ respectively with a $p<0.0001$. Highly significant improvement is found in subjective and objective parameters.

Conclusion: This data suggests that the test drugs were safe, effective in improving and relieving symptoms of cervical erosion. Further, research in a larger sample size for longer duration is recommended.

Key Words: Quruhalrahim, Cervical ectopy, Abzan, Arbitrary grading scale, SF-12 for QOL, Vaginal discharge

\section{INTRODUCTION}

Cervical erosion is also known as cervical ectopy. It is a benign lesion and a common gynaecological condition seen in outpatient departments. ${ }^{1,2}$ About $80-85 \%$ of women suffer from cervical erosion. ${ }^{3}$ It is the commonest finding in routine pelvic examinations during the fertile age group $1 .{ }^{1}$ Pathologically cervical erosion is a condition where squamous epithelium of the ectocervix is replaced by the columnar epithelium of the endocervix. ${ }^{3}$ The exposed columnar epithelium looks red because of the blood vessels just below the surface. ${ }^{4}$ A single layer of glandular cells that reside in close association with the underlying vascular cervical stroma appear. It is thin and vascularized epithelium fragile tissue. With easy access to the blood and lymphatic systems, there are decreased mucosal barriers to sexually transmitted infections (STIs), including HIV. Prior observational epidemiological studies have suggested that cervical ectopy can increase the risk of acquiring diseases like chlamydia trachomatis, human papillomavirus, and cytomegalovirus, but not Neisseria gonorrhoea. ${ }^{5}$

The common causes of ectopy are trauma by multiple childbirths, tampon use of intrauterine contraceptive device chemicals, infections, hormones (oral contraceptive pills) or carcinoma etc. Cervical ectopy is more common in women of lower socioeconomic groups, poor general hygiene, early marriage and multiple pregnancies. ${ }^{6}$ Clinically, the patient may present with vaginal discharge, low backache, contact bleeding in the form of post-coital bleeding or intermenstru-

\section{Corresponding Author:}

Dr. Shamim Ansari, Research Scholar, Department of Ilmul Qabalat wa Amraze Niswan (OBG.) NIUM, Bengaluru - 560091, Karnataka, India; E-mail: dr.shamimiqbal74@gmail.com.

ISSN: 2231-2196 (Print) ISSN: 0975-5241 (Online)

Received: $13.07 .2020 \quad$ Revised: 23.09 .2020

Accepted: 03.11 .2020

Published: 03.02 .2021 
al bleeding, dyspareunia, etc. ${ }^{7}$ Cervical erosion is diagnosed by per speculum examination. It reveals a bright red area surrounding and extending beyond the external os in the ectocervix. The outer edge is demarcated. It may be smooth or having small papillary folds. It is neither tender nor bleeds to touch. ${ }^{7}$ It is asymptomatic and physiological then needs no treatment but when it is symptomatic and infected then the treatment is needed., ${ }^{3,7}$ Cryo-cauterization, electrocoagulation and cautery with laser is the treatment of choice. Side effects like prolonged excessive mucoid discharge per vagina, seldom cervical stenosis, accidental burns, bleeding and recurrence are associated with this treatment. ${ }^{6}$ In classical Unani literature which is caused by external factors such as wound due to trauma, instrumentation, the drug which is caused by external factors such as wounds due to trauma, instrumentation, drug-induced i.e use of haad drugs in the form of humool, or internal factors like difficult labour or mismanagement of labour, sometimes, it may be because of acute yellow bile causing gradual erosion of cervix due to its acute nature or inflammation and rupture of pustules. ${ }^{8,9}$ In symptoms like backache, pelvic pain, abnormal vaginal discharge, excessive tiredness etc. Use of (relaxant) drugs is harmful while qabiz (astringent) drugs are beneficial in its treatment. ${ }^{8-10}$

Unani system of medicine has several drugs available for healing of cervical ectopy as a local treatment in the form of a sit bath, which is safe and cost-effective. In present study research drug comprises of Methi (Trigonella foenum graeceum) 5 gms, alsi (Linum usitatissimum) $5 \mathrm{gms}$, babuna (Matricaria chaemomilla) 3gms, nakhuna ((Trigonella uncata) $5 \mathrm{gms}$, karmkalla ka dant'hal (Brassica oleracea) $10 \mathrm{gms}$ Joshanda is prepared in 2 lots of warm water. After menses use daily one-time forsitz bath for 15 minuts for 21 days. ${ }^{11}$ In unani system of medicine various drugs with medicinal properties like munzij, muhallilawram (anti-inflammatory), jaali (detergent), muqawiebadan, mushil ( laxative), mиjaffif, mudammilquruh, dafi-i-taffun, mullayan, mussakinetc are used locally to treat this disease.

\section{MATERIALS AND METHODS}

Study design: An open observational study.

Study duration: One and a half years from March 2019 to January 2020

Study centre: OBG Dept. National Institute of Unani Medicine Hospital, Bangalore.

Sample size: 30 patients

Ethical clearance No.: Ethical clearance was obtained from the institutional ethical committee vide no NIUM/ IEC/2017-18/013/ANQ/05; and CTRI registration done vide no.CTRI//2019/03/024426.
Informed consent: all participants gave written informed consent before study

Drugs Identification: was done at FRLHT Bengaluru. with an acc. No. 5510-5514

Participants: Total 60 patients were screened for the study, 10 patients refused participation and 20 patients didn't meet the inclusion criteria, hence were excluded. 30 patients were allocated in- an open observational study.

Selection criteria: Married women between the age group of 18-45 yrs. Having symptoms of vaginal discharge, low backache, dyspareunia, post-coital bleeding, normal or inflammatory changes in pap smear were included and patients with malignancy, PID, systemic illnesses like Hypertension, diabetes mellitus \& STIs, OC Pills and IUCD's, pregnancy and lactation were excluded.

Study procedure: The patients fulfilling the inclusion criteria were enrolled after explaining the study in detail and receiving informed consent. In each patient, history was evaluated and a complete physical examination including breast, abdominal examination and per vaginal examination was performed. Personal details, history, clinical features and investigations were recorded in the Case record form structured for the study.

Criteria for selection of drug: the research drug possess properties like muhallilewaram, mujaffif, mudammilequruh, dafi-i- ta'ffun,qabid, musakkin, ${ }^{12-17}$ properties. Moreover, pharmacological studies show that research drug exhibit anti microbial, anti-inflammatory, anti oxidant, anti-cancer, anti-ulcer, analgesic, hepatoprotective wound healing activities. ${ }^{13,14,18-20,}$ Further methi, alsi, nakhoona, baboona, karamkallacontains flavonoids, saponins (glycosides), alkaloids (terpenoids, steroids) arachidonic acid, ethanol, histamine, leukotriens, polysaccharides, saponins (glycosides), carbohydrates, tannins, triglisoraletc; ${ }^{13,14,18}$, which are considered as the active principle of anti-ulcer activity. Flavonoids are a group of a polyphenolic compound having anti-ulcerogenic, anti-inflammatory, anti-bacterial, antioxidants properties ${ }^{4}$ which provide strength to the mucosal barrier \& promote the ulcer to heal fast. ${ }^{20}$ The wound healing activity of Unani formulation as abzan might protect against microbial invasion by providing better tissue formation. Further, it enhances the rate of wound healing $\&$ tissue epithelization ${ }^{4}$ Thus, research Unani formulation is anticipated to be effective in the healing of cervical ectopy and relieving the associated symptoms.

\section{Method of preparation}

The best quality of methi, alsi, babuna, nakhuna, and karmkalla was provided by the pharmacy of NIUM, and was further authenticated by FRLHT Bengaluru. with an acc. No. 5510-5514. All the drugs were finely powdered. Drugs were weighed and mixed. The powdered drugs were dispatched in 
plastic self-lock bags. To avoid any confusion regarding dosages one lock bag was used to dispatch $28 \mathrm{gm}$ of the drug for a single day which was to be used daily for one measure for sitz bath. So every patient was given 7 packets of the drug for one week at each visit and continued for 3 weeks.

\section{Route of administration: Locally}

\section{Initial assessment and laboratory screening}

1. Baseline Laboratory investigations like haemoglobin percentage, total leucocyte count, differential leucocyte count, erythrocyte sedimentation rate, Veneral Disease Research Laboratories test and random blood sugar were done to exclude general diseases. Ultrasonography of pelvis was done to exclude pelvic pathology. Pap smear was done to exclude genital malignancy in each case.

2. Assessment of the extent of erosion was graded as 0,1 , 2 and3; as follows. Grade 0: No erosion Grade 1: covering $1 / 3^{\text {rd }}$ of cervix Grade 2 : from $1 / 3^{\text {rd }}$ to $2 / 3^{\text {rd }}$ area of the cervix, and Grade 3: overs $2 / 3^{\text {rd }}$ of the cervix. The assessment was done before treatment, at each follow up during treatment and after treatment. Patients were also enquired for any side effects during the trial.

3. Assessment of Health-related quality of life (HRQol) was assessed by the SF-12 questionnaire.

4. Assessment of low backache is done by using the Visual Analogue Scale (VAS)

5. Assessment of vaginal discharge was graded from 0 to 4 grade: score: 1-No discharge; 2- Mild ( No staining or moistness of undergarments); 3-Moderate (stain on undergarments); Score:4- severe (using pads).

6. Dyspareunia and post-coital bleeding were based on the arbitrary four-point scale $(0=$ None, $1=$ Mild, $2=$ Moderate, $3=$ Severe ).

Treatment was subsequently started in patients fulfilling the inclusion criteria.

\section{Intervention}

Joshanda of methi (Trigonella foenum graceum) $5 \mathrm{gms}$, alsi (Linum usitatissium graceum) 5gms, babuna (Matricaria chaemomilla) 3gms, nakhuna (Trigonella uncata) 5gms, karmkalla ka danthal (Brassica oleracea) 10gms was prepared by soaking the drugs in $400 \mathrm{ml}$ of water for the whole night. Next day in the morning the soaked drugs with water was boiled until it was concentrated to $180 \mathrm{ml}$. Abzan were prepared according to the standard method of preparation. It was used for 15 minuts daily for 21 days after menses. Assessment of erosion and health-related quality of life (HRQol) was done at baseline, each follow up during treatment (weekly) and after treatment (once in 15 days for a month). Patients were also enquired for any side effects during the trial. Patients were advised to maintain personal hygiene and avoid intercourse during the treatment.

\section{Subjective parameters}

Vaginal discharge, low backache, contact bleeding, dyspareunia

\section{Objective parameters:}

1. Changes in Cervical ectopy assessed by the arbitrary grading scale

(Direct visual assessment of the appearance of cervix, healing of erosion and vaginal discharge).

2. SF-12 score to assess for QOL

\section{Outcome measures:}

Primary outcome measure: changes in white discharge and low backache.

Secondary outcome measure: Improvement in cervical ectopy grading and SF-12 (12 items short-form survey) Health Questionnaire score (Figure 1).

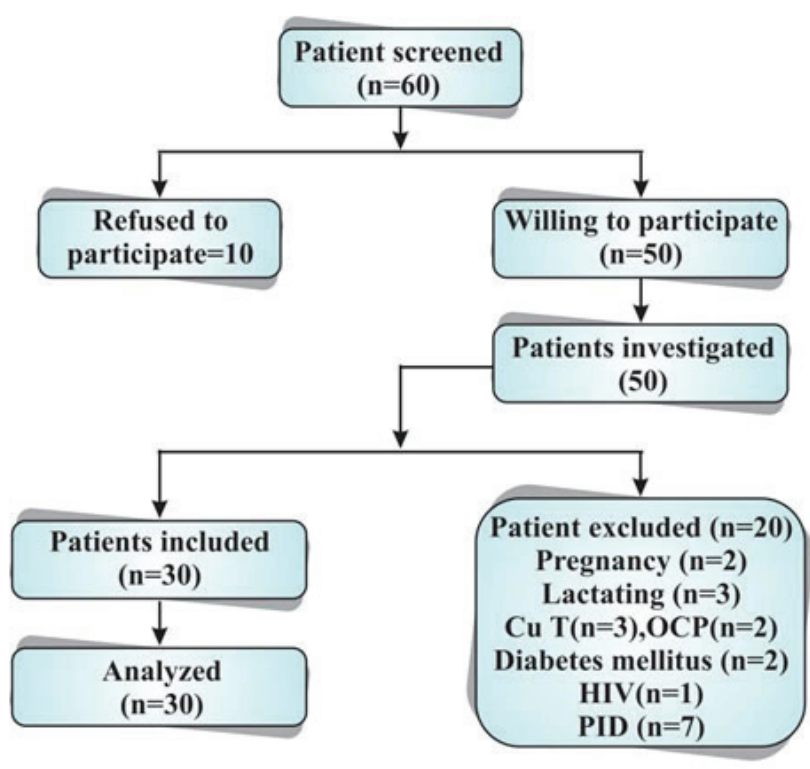

Figure 1: Study design.

\section{Statistical analysis}

Descriptive and inferential statistical analysis has been carried out in the present study. Results on continuous measurements are presented on Mean SD (Min-Max) and results on categorical measurements are presented in Number (\%). Significance is assessed at $5 \%$ level of significance. The Statistical software namely SPSS 22.0, and R environment ver.3.2.2 were used for the analysis of the data and Microsoft Word and Excel have been used to generate graphs, tables etc. 22,23 


\section{RESULTS AND DISCUSSION}

\section{Demographic characteristics}

Age: Majority of the patients (63.3\%) were in the age group of $31-40$ years \& remaining $30 \%$ were in $21-30$ years and $6.7 \%$ in $41-50$ years of age. Hashmi et $\mathrm{al}^{24}$, Mirza et al ${ }^{25}$, Patil et al 26 and Latafat et al. ${ }^{27} 40 \%$ and $44 \%$ in two groups in 31 35 yrs, reported $39.2 \%$ in $31-40$ yrs., reported $40 \% \& 37.8 \%$ in 26-30 yrs. respectively. The result of present study correlates with the above studies. Evidence suggests that cervical ectopy is common in women of reproductive age group. ${ }^{4,7}$ Mean \pm SD of age of patients was $33.93 \pm 5.37$, which is in accordance with the study of Jindal et al. ${ }^{2}$ who reported 31.32 and 33.7 in two groups, Al- Kaseer reported ${ }^{28} 27.1 \pm 5.9$, Cekmez et al. ${ }^{29}$ reported $34.4 \pm 4.3$.

Socioeconomic status: In present study, $23.3 \%$ patients belongs to upper middle class, $63.3 \%$ to lower middle class; and $13 \%$ to lower class. Hashmi S et al. ${ }^{24}$ reported $43.3 \%$ patients in upper lower, $36.6 \%$ in upper middle, $16.6 \%$ in lower middle and $13.3 \%$ in lower class. Mirza et al. ${ }^{25}$ reported $42.2 \%$ patients in upper lower class, $40 \%$ in lower middle, $11.1 \%$ in upper middle $\& 6.7 \%$ in upper class. Shivanna et al. ${ }^{30}$ reported $72 \%$ and $75 \%$ patients respectively from low Socioeconomic status. Gautam et al. ${ }^{31}$ reported majority of the patients belong to lower middle class. Bengal et al. ${ }^{32}$ reported that maximum patients having cervical ectopy belong to low socioeconomic class, low literacy level, poor personal hygiene and poor health awareness. Literature report says that low socio economic status predispose to poor nutrition, poor personal hygiene leading to infection which may cause cervical ectopy. ${ }^{32,33}$

Literary status: Most of the patients had low educational level i.e.; $36.7 \%$ patients had primary school education, while $13.3 \%$ were illiterate, $23 \%$ \& $16.7 \%$ had education up to secondary and higher secondary school while graduate and post graduate are $6.7 \%$ and $3.3 \%$ respectively. Mirza et al. ${ }^{25}$ reported $20 \%$ illiterate, $33.3 \%$ had middle school education, $10 \%$ each in primary school and high school \& $13.3 \%$ graduate. Hashmi S et al. ${ }^{24}$ reported $44.44 \%$ illiterate, $20 \%$ had middle school education \& $13.3 \%$ had education in each primary, secondary and higher secondary. Gautam et al. ${ }^{31}$ reported $40 \%$ of the patients had high school education. Al-Kaseer et al. ${ }^{28}$ reported low educational level among patients of cervical ectopy.

Occupation: In this study house wife are more affected than the working class. Out of 30 patients $73.3 \%$ of patients are of house wife affected with cervical erosions where as $26.7 \%$ are working women.

Dietetic habit: In this study out of 30, 20 (66.7\%) patients are of mix diet. Whereas $10(33.3 \%)$ are vegetarian. In Una$n i$ system of medicine importance has been given to dietetics in health and disease. ${ }^{34}$ Unani physicians mentioned certain foods which are to be taken and to be avoided according to age, season, place, and mizaj of the person. The temperament of meat is har, when consumed in excessive quantity; it causes increase production of khilte dam, and can lead to amrazedamvi. As, mentioned earlier that cervical erosion with cervicitis is a damvi marz, ${ }^{35}$ it may be assessed that non vegetarian diet has its impact on this disease as per the mizaj and akhlat theory.

Mizaj: Most of the patients, $86.7 \%$ possessed damwimizaj, while $13.3 \%$ had balghamimizaj, none of the patients had safrawi or saudawimizaj, which is in consonance with the studies of Hashmi et al. ${ }^{24}$ reported $66.67 \%$ patients with damwimizaj, Mirza et al. ${ }^{25}$ reported $53.3 \%$ with damwimi$z a j$. Moreover, it coincides well with the theories of eminent Unani Scholars in etiopathogenesis of quruh, who states that hararat and ratubat are essential component of ufunat which forms an inflammatory swelling and when it get secondarily infected, it result in rupture of this swelling which in turn leads to ulcer formation. ${ }^{10,36}$.

Table 1: Baseline characteristics.

\begin{tabular}{lcc} 
Age in years & No. of patients $(\mathbf{N}=\mathbf{3 0})$ & $\%$ \\
\hline $21-30$ & 9 & 30.0 \\
$31-40$ & 19 & 63.3 \\
$41-50$ & 2 & 6.7 \\
Mean \pm SD: 33.93 $\pm 5 \cdot 37$ P > 0.10 & & \\
Socio Economic Status & & \\
Lower & 4 & 13.3 \\
Lower Middle & 19 & 63.3 \\
Upper Middle & 7 & 23.3 \\
Occupation & & \\
H.W. & 22 & 73.3 \\
Others & 8 & 26.7 \\
Diet & & \\
Mixed & 20 & 66.7 \\
Veg & 10 & 33.3 \\
Literary status & & \\
Ill & 4 & 13.3 \\
Prim & 11 & 36.7 \\
Sec. & 7 & 23.3 \\
Hr. Sec. & 5 & 16.7 \\
Graduate & 2 & 6.7 \\
Post G. & 1 & 3.3 \\
\hline & & \\
\hline & & \\
\hline
\end{tabular}

\section{Subjective parameters}

Vaginal discharge: At baseline, all patients were complaining of vaginal discharge. During treatment, on $1^{\text {st }} \& 2^{\text {nd }}$ follow up, it persists in $96.3 \%$ and was absent in $3.3 \%$ patients respectively. After treatment, it persists in $36.7 \%$ with mild 
discharge. \& was absent in $63.3 \%$.At baseline, vaginal discharge was mild, moderate \& severe in $3.3 \%, 56.7 \%$ \& $40 \%$ patients respectively. During treatment, on $1^{\text {st }}$ follow up vaginal discharge was mild \& moderate and severe in 3.3\%, $70 \%$ and $26.7 \%$ patients respectively, whereas none of the patients had severe vaginal discharge; on $2^{\text {nd }}$ follow up, vaginal discharge was not present in $3.3 \%$ and $26.7 \%$ and $70 \%$ patients had mild and moderate vaginal discharge respectively. After treatment, vaginal discharge was mild in $36.7 \%$ \& absent in $63.3 \%$ patients, though no patient had moderate and severe vaginal discharge. After treatment, vaginal discharge with mean of $2.37 \pm 0.57$ and $0.367 \pm 0.49$ before and after intervention with $\mathrm{P}<0.001$, considered as highly significant, which is consistent with the study of Gupta P et al., ${ }^{37}$ Monroy $\mathrm{OL}^{38}$ \& Anees $\mathrm{S},{ }^{39}$ studies who reported vaginal discharge in $100 \%$ patients before treatment and relief in $86.6 \%$ after treatment. Cekmez Y et al. ${ }^{29}$ reported vaginal discharge in $91.9 \%$ patients with complete relief in $89.5 \%$.Kamini $\mathrm{D}^{3}$ reported $93.45 \%$ and Hashmi S et al. ${ }^{24}$ reported $100 \%$ improvement in vaginal discharge. Moreover, research drug possess muhallilewaram, daffi-i- tafun, anti-microbial, anti-fungal, anti-viral activities, which might resolve the inflammation after removing the infection and thus improves the vaginal discharge (Table 2)..$^{14,16,17,19,40-43}$

The unani formulation was most successful in managing white discharge as all 30 patients presenting with vaginal discharge were having no discharge after the treatment. Other associated symptoms of cervicitis like low backache, lower abdominal pain, and dyspareunia were significantly relieved. Pharmacological studies reported that methi, alsi, babuna, nakhunaand karamkalla $^{12}$ are proved for antimicrobial effect that may have inhibit the growth of organism and also these drugs are having anti-inflammatory property. ${ }^{18,40,45}$ The improvement in these symptoms is most probably because of the effect of the test drugs having musaffikhoon, muhallil, dafetaffun, qabiz, mujaffifqurooh properties and baridwayabismiz. ${ }^{46}$ As discussed earlier in etio-pathogenesis zoefequwateghazia is one of the main causes of saylanurrahim that leads to this disease and baridwayabismizaj of drugs tone up the quwateghazia of rahim $^{10}$ and thereby rectifying the quality and quantity of khilte dam. Further, astringent drugs have been reported to decrease the secretions, which may have inhibitory effect.

Table 2: Assessment of Vaginal Discharge in cervical erosion patients studied.

\begin{tabular}{|c|c|c|c|c|c|c|}
\hline Vaginal Discharge & $\begin{array}{c}\text { Before } \\
\text { Treatment }\end{array}$ & $\begin{array}{c}\text { I } \\
\text { Follow up }\end{array}$ & $\begin{array}{c}\text { II } \\
\text { Follow up }\end{array}$ & $\begin{array}{c}\text { III } \\
\text { Follow up }\end{array}$ & $\begin{array}{c}\text { After } \\
\text { Treatment }\end{array}$ & $\begin{array}{c}\% \\
\text { Difference }\end{array}$ \\
\hline Nil & o(o\%) & $\mathrm{o}(\mathrm{o} \%)$ & $1(3 \cdot 3 \%)$ & $2(6.7 \%)$ & $19(63 \cdot 3 \%)$ & $63.3 \%$ \\
\hline Mild & $1(3 \cdot 3 \%)$ & $1(3 \cdot 3 \%)$ & $8(26.7 \%)$ & $24(80 \%)$ & $11(36.7 \%)$ & $33.4 \%$ \\
\hline Moderate & $17(56.7 \%)$ & $21(70 \%)$ & $21(70 \%)$ & $4(13 \cdot 3 \%)$ & $\mathrm{o}(\mathrm{o} \%)$ & $-56.7 \%$ \\
\hline Severe & $12(40 \%)$ & $8(26.7 \%)$ & $\mathrm{o}(\mathrm{o} \%)$ & o(o\%) & $\mathrm{o}(\mathrm{o} \%)$ & $-40.0 \%$ \\
\hline Total & $30(100 \%)$ & $30(100 \%)$ & $30(100 \%)$ & $30(100 \%)$ & $30(100 \%)$ & - \\
\hline Mean \pm sd & & BT $2.37 \pm 0.56$ & & & AT $0.37 \pm 0.49$ & \\
\hline$P$ value & \multicolumn{6}{|c|}{$\mathrm{P}<0.0001$} \\
\hline
\end{tabular}

Test used: Paired proportion test

Low backache: After treatment, compared to baseline low backache was relieves in $90 \%$ patients with mean of $1.93 \pm 0.37$ and $0.1 \pm 0.36$ before and after intervention respectively, with $\mathrm{P}<0.0001$ considered as highly significant. Anees ${ }^{39}$ reported $100 \%$ patient's with complaining of low back pain and relief in $66.7 \%$. Mirza et $\mathrm{al}^{25}$ reported $53.3 \%$, Hashmi et al. ${ }^{24}$ reported $30 \%$, Kamini ${ }^{3}$ reported $64 \%$, and Al-Kaseer et al. ${ }^{28}$ reported $65 \%$ improvement in low backache. low backache at baseline, after treatment was nil, mild, moderate, and se- vere, ie $90 \%, 10 \%, 0 \%, 0 \%$ respectively with $\mathrm{P}<0.001$, considered as highly significant, which is in accordance with the studies of Kamini et al. ${ }^{3}$ reported $1.26 \pm 0.4$ and $0.46 \pm 0.4$, Sharma et al. ${ }^{44}$ reported $1.90 \pm 0.60$ and $0.95 \pm 0.60 \&$ Gautam et al. ${ }^{31}$ reported $1.12 \pm 0.169$ and $0.75 \pm 0.619$ as Mean \pm SD of low backache before and after treatment. Moreover, research drug possess muhallilewaram, musakkin, anti-inflammatory, analgesic, sedative activities which might resolve the inflammation and hence improves low backache (Table 3). ${ }^{14,16,17,19,40-43}$

Table 3: Assessment of Low Backache of in cervical erosion patients studied.

\begin{tabular}{|c|c|c|c|c|c|c|}
\hline Low Backache & BT & I-FU & II-FU & III-FU & AT & \% Difference \\
\hline Nil & $\mathrm{o}(\mathrm{o} \%)$ & $\mathrm{o}(\mathrm{o} \%)$ & $1(3.3 \%)$ & $13(43 \cdot 3 \%)$ & $27(90 \%)$ & $90.0 \%$ \\
\hline Mild & $3(10 \%)$ & $6(20 \%)$ & $26(86.7 \%)$ & $17(56.7 \%)$ & $3(10 \%)$ & $0.0 \%$ \\
\hline Moderate & $26(86.7 \%)$ & $24(80 \%)$ & $3(10 \%)$ & $\mathrm{o}(\mathrm{o} \%)$ & $\mathrm{o}(\mathrm{o} \%)$ & $-86.7 \%$ \\
\hline Severe & $1(3.3 \%)$ & $\mathrm{o}(\mathrm{o} \%)$ & $\mathrm{o}(\mathrm{o} \%)$ & $\mathrm{o}(\mathrm{o} \%)$ & $\mathrm{o}(\mathrm{o} \%)$ & $-3.3 \%$ \\
\hline Total & $30(100 \%)$ & $30(100 \%)$ & $30(100 \%)$ & $30(100 \%)$ & $30(100 \%)$ & - \\
\hline Mean \pm SD & & & BT $1.93 \pm 0.37$ & & AT $\mathrm{c}$ & \\
\hline P value & & & $\mathrm{P}<0.0001$ & & & \\
\hline
\end{tabular}

Test used: Paired proportion test 
Dyspareunia: Dyspareunia in $70 \%$ of patients with mild and moderate $46.7 \%$ and $23.4 \%$ respectively was observed. Whereas $30 \%$ of patients are free of dyspareunia. In first follow-up of treatment $36.7 \%$ are free with dyspareunia in mild and $20 \%$ in moderate dyspareunia patients. Where as in second follow up $46.7 \%$ patients were free of dyspareunia where as $53.3 \%$ were having mild dyspareunia. Where as in third follow up it is improved to $80 \%$ with dyspareunia free and $20 \%$ with mild Dyspareunia. The mean is $0.93 \pm 0.734$ and $0.03 \pm 0.18$ before and after treatment respectively with $\mathrm{p}<0.0001$ which is highly significant. After treatment $96.7 \%$ patients are free of this symptom with a $\%$ difference of 66.7 , and $3.3 \%$ with mild dyspareunia with a\% difference of -43.4 (Table 4).

Table 4: Assessment of Dyspareunia in cervical erosion patients studied.

\begin{tabular}{|c|c|c|c|c|c|c|}
\hline Dyspareun-ia & BT & I-FU & II-FU & III-FU & $\mathrm{AT}$ & \% Difference \\
\hline Nil & $9(30 \%)$ & $11(36.7 \%)$ & $14(46.7 \%)$ & $24(80 \%)$ & $29(96.7 \%)$ & $66.7 \%$ \\
\hline Mild & $14(46.7 \%)$ & $13(43 \cdot 3 \%)$ & $16(53 \cdot 3 \%)$ & $6(20 \%)$ & $1(3.3 \%)$ & $-43.4 \%$ \\
\hline Moderate & $7(23.3 \%)$ & $6(20 \%)$ & $\mathrm{o}(\mathrm{o} \%)$ & $\mathrm{o}(\mathrm{o} \%)$ & $\mathrm{o}(\mathrm{o} \%)$ & $-23.3 \%$ \\
\hline Severe & $\mathrm{o}(\mathrm{o} \%)$ & $\mathrm{o}(\mathrm{o} \%)$ & $\mathrm{o}(\mathrm{o} \%)$ & $\mathrm{o}(\mathrm{o} \%)$ & $\mathrm{o}(\mathrm{o} \%)$ & $0.0 \%$ \\
\hline Total & $30(100 \%)$ & $30(100 \%)$ & $30(100 \%)$ & $30(100 \%)$ & $30(100 \%)$ & - \\
\hline Mean \pm sd & & & BT $0.93 \pm 0.74$ & & \multicolumn{2}{|c|}{ AT $0.03 \pm 0.18$} \\
\hline P value & & & $\mathrm{P}<0.0001$ & & & \\
\hline
\end{tabular}

Test used: Paired proportion test

Contact bleeding: In this study out of 30 patients 25 (83.4\%) had contact bleeding. with mild in $14(46.7 \%)$, moderate in $9(30 \%)$ and severe in $2(6.7 \%)$ patients. In first follow up of treatment one severe case of contact bleeding responded well. Where as in second follow up $43.3 \%$ are free of contact bleeding. Whereas $46.7 \%$ had mild type and $6.7 \%$ had moderate and $3.3 \%$ has severe contact bleeding. In third fol- low up $70 \%$ got relieved totally from contact bleeding and only $26.7 \%$ had mild contact bleeding and $3.3 \%$ had moderate bleeding in patients of cervical erosion. The mean is $1.27 \pm 0.83$ and $0.03 \pm 0.18$ before and after intervention with $\mathrm{p}<0.0001$ which is highly significant. After treatment $96.7 \%$ of patients are free of contact bleeding and $3.3 \%$ with mild contact bleeding. This show the effect of abzan of unani formulation as mentioned in unani literature (Table 5).

Table 5: Assessment of Contact bleeding in cervical erosion patients studied.

\begin{tabular}{|c|c|c|c|c|c|c|}
\hline Contact Bleeding & BT & I-FU & II-FU & III-FU & AT & \% Difference \\
\hline Nil & $5(16.7 \%)$ & $5(16.7 \%)$ & $13(43.3 \%)$ & $21(70 \%)$ & $29(96.7 \%)$ & $80.0 \%$ \\
\hline Mild & $14(46.7 \%)$ & $14(46.7 \%)$ & $14(46.7 \%)$ & $8(26.7 \%)$ & $1(3 \cdot 3 \%)$ & $-43.4 \%$ \\
\hline Moderate & $9(30 \%)$ & $10(33 \cdot 3 \%)$ & $2(6.7 \%)$ & $1(3.3 \%)$ & $\mathrm{o}(\mathrm{o} \%)$ & $-30.0 \%$ \\
\hline Severe & $2(6.7 \%)$ & $1(3.3 \%)$ & $1(3.3 \%)$ & $\mathrm{o}(\mathrm{o} \%)$ & $\mathrm{o}(\mathrm{o} \%)$ & $-6.7 \%$ \\
\hline Total & $30(100 \%)$ & $30(100 \%)$ & $30(100 \%)$ & $30(100 \%)$ & $30(100 \%)$ & - \\
\hline Mean \pm SD & & & BT $1.27 \pm 0.83$ & & \multicolumn{2}{|c|}{ AT $0.03 \pm 0.18$} \\
\hline P value & & & \multicolumn{4}{|c|}{$\mathrm{P}<0.0001$} \\
\hline
\end{tabular}

Test used: Paired proportion test

\section{Objective parameters}

Cervical ectopy grading: At base line, cervical ectopy was observed in $100 \%$ patients, which remains in $43.3 \%$ patients after treatment. Cervical ectopy was in grade I in $40 \%$ patients, grade II in $50 \%$ \& grade III in $10 \%$; during treatment, After treatment, on $1^{\text {st }}$ follow up, $40 \%$ patients had cervical ectopy in grade I, 3.3\% in grade II and none of the patient had cervical ectopy in grade III; Thus, cervical ectopy was reduced in $43.3 \%$ and cured in $56.7 \%$ patients with $\mathrm{P}=0.0054$, considered as highly significant.
The mean is $1.7 \pm 0.66$ and $0.47 \pm 0.58$ before and after intervention with $\mathrm{p}<0.0001$ which is highly significant. Shivana et al. ${ }^{30}$ reported healing of cervical ectopy in $60 \%$ patients after 7 days, $30 \%$ after 14 days and $10 \%$ after 21 days of treatment. Sharma et al. ${ }^{44}$ reported improvement in $65.85 \%$ patients, Cekmez et al. ${ }^{29}$ reported in $95.9 \%$ patients after 6 weeks. Gautam et al ${ }^{31}$ reported improvement in $53.4 \%$ patientsafter 7 days. Hence, complete healing of cervical ectopy as observed in $20 \%$ patients only after 2 weeks of treatment. Moreover, research drug possess mussakin, muhallil- $i$ - auram mullayan, mujaffif, mudammillequruh, qabid, antiulcer, antioxidant \& wound healing activities, 
which might be helpful in healing of cervical erosion (Table 6). ${ }^{14,16,17,19,40-43}$

\begin{tabular}{|c|c|c|c|}
\hline Grade & $\begin{array}{l}\text { Before } \\
\text { Treatment }\end{array}$ & After Treatment & $\%$ Difference \\
\hline o & $\mathrm{o}(\mathrm{o} \%)$ & $17(56.7 \%)$ & $56.7 \%$ \\
\hline 1 & $12(40 \%)$ & $12(40 \%)$ & $0.0 \%$ \\
\hline 2 & $15(50 \%)$ & $1(3 \cdot 3 \%)$ & $-46.7 \%$ \\
\hline 3 & $3(10 \%)$ & $\mathrm{o}(\mathrm{o} \%)$ & $-10.0 \%$ \\
\hline Total & $30(100 \%)$ & $30(100 \%)$ & - \\
\hline Mean \pm sd & $1.7 \pm 0.66$ & $0.47 \pm 0.58$ & \\
\hline$P$ value & & \multicolumn{2}{|c|}{$\mathrm{P}<0.0001$} \\
\hline
\end{tabular}

Test used: Paired proportion test

QOL by SF-12 score: Cervical erosion with its symptoms has a broad impact on HRQoL and puts a heavy economic burden on society. ${ }^{47}$ The mean \pm SD before intervention was $382.73 \pm 52.33$ and after it was $910.17 \pm 56.30$ with mean difference of 910.17 and $p$ value $<0.0001$. It shows strongly significant improvement in the quality of life (Table.7).

Table 7: Assessment of SF-12 in cervical erosion patients studied.

\begin{tabular}{lccc} 
SF-12 & BT & A T & $\%$ difference \\
$<300$ & $2(6.7 \%)$ & $0(0 \%)$ & $-6.7 \%$ \\
$300-400$ & $15(50 \%)$ & $0(0 \%)$ & $-50.0 \%$ \\
$>400$ & $13(43.3 \%)$ & $30(100 \%)$ & $56.7 \%$ \\
Total & $30(100 \%)$ & $30(100 \%)$ & - \\
Mean \pm sd & $382.73 \pm 52.33$ & $910.17 \pm 56.301$ & \\
P< 0.0001 & & & \\
\hline
\end{tabular}

Test used: Paired proportion test

\section{Primary outcome measures}

Vaginal discharge: the mean of vaginal discharge before and after treatment is $2.37 \pm 0.57$ and $0.37 \pm 0.49$ respectively with a $\mathrm{P}<0001$. Improvement in vaginal discharge was nted in $90 \%$ patients; while it persist in $10 \%$ patients after 2 weeks of treatment; Anees $\mathrm{S}^{31}$ reported $86.6 \%$ after 1 week, Jindal $\mathrm{M}^{2}$ reported $100 \%$ and $92 \%$ in two groups after 4-6weeks of treatment (Table 8).

Low backache: The mean \pm sd of low back ache before intervention was $1.93 \pm 0.37$ and after it was $0.1 \pm 0.36$ with mean difference of $90.0 \%$ and $p$ value $<0.0001$. Absence of low back ache was noted in $90 \%$ patients, where it was in mild in $10 \%$ of patients after 3 weeks of treatment, which correlating with the study of Jindal $\mathrm{M}^{2}$ reported relief in $96 \%$ \& $76 \%$ in two groups after 4-6weeks of treatment (Table 8).

Dyspareunia: The mean is $0.93 \pm 0.74$ and $0.03 \pm 0.18$ before and after treatment respectively with $\mathrm{p}<0.0001$ which is highly significant. This study shows dyspareunia is absent in the $96.7 \%$ of patients with mild in $3.3 \%$.. In first follow-up of treatment $36.7 \%$ are free with dyspareunia 43.3 in mild and $20 \%$ in moderate had dyspareunia. Where as in second follow up $46.7 \%$ patients were free of dyspareunia where as $53.3 \%$ were having only mild dyspareunia. In third follow up in $80 \%$ were dyspareunia free and $20 \%$ with mild Dyspareunia. After treatment $96.7 \%$ patients are free of this symptom with a $\%$ difference of 66.7 , and $3.3 \%$ with mild dyspareunia with $\mathrm{a} \%$ difference of -43.4 . It show that unani formulation having muhallileawram, jail, mussakinealam etc. properties helps in relieving pain (Table 8).

Contact bleeding: The mean is $1.27 \pm 0.83$ and $0.03 \pm 0.18$ before and after intervention with $\mathrm{p}<0.0001$ which is highly significant. In this study patients with contact bleeding, mild in $14(46.7 \%)$, moderate in $9(30 \%)$ and severe in $2(6.7 \%)$ patients. In first follow up of treatment one severe case of contact bleeding responded well. In second follow up $43.3 \%$ are free of contact bleeding. Whereas $46.7 \%$ had mild type and $6.7 \%$ had moderate and $3.3 \%$ has severe contact bleeding. In third follow up $70 \%$ got relieved totally from contact bleeding and only $26.7 \%$ had mild contact bleeding and $3.3 \%$ had moderate bleeding. After treatment $96.7 \%$ of patients are free of contact bleeding and $3.3 \%$ are with mild contact bleeding with $\%$ difference of $80.0 \%$ (Table 8 ). This show the effect of abzan of unani formulation as mentioned in unani literature.

\section{Secondary outcome measure}

Cervical ectopy grading: complete healing of cervical ectopy was observed in $56.7 \%$ patients \& no improvement in $43.3 \%$ patients after 3 weeks of treatment. The mean is $1.7 \pm 0.65$ and $0.47 \pm 0.58$ before and after intervention with $\mathrm{p}<0.0001$ which is highly significant. Hashmi S et al. ${ }^{24} \mathrm{re}-$ ported cure in $26.66 \%$ patients after 9 weeks of treatment. Shivanna $\mathrm{S}$ et al. ${ }^{30}$ reported in $60 \%$ patients after 1 week and in $40 \%$ after 3 weeks of local application of albothyl solution. Jindal $\mathrm{M}$ et al. ${ }^{2}$ reported $92 \% \& 76 \%$ respectively in two groups (electro cautery/ cryocautery) after 4-6weeks. Cekmez et al. ${ }^{29}$ reported in $95.9 \%$ patients after 6 weeks of cryocautery (Table 8).

QOL by SF-12 score: The eight domains of SF-12 measures are as follows: physical functioning role: role limitations due to physical health, role limitation due to emotional problems, energy /fatigue, emotional wellbeing social functioning, pain general health. ${ }^{47}$ The mean \pm sd before intervention was $382.73 \pm 52.33$ and after it was $910.17 \pm 56.30$ with mean difference of 910.17 and $p$ value $<0.0001$. It shows strongly significant improvement in the quality of life. Cervical erosion with its symptoms has a broad impact on HRQoL and puts a heavy economic burden on society (Table 7). Hence the unani formulation makes a strongly significant change in SF-12 score hence improvement in quality of life (Table 8). 
Table 8: Assessment of primary and secondary outcome in cervical erosion patients

\begin{tabular}{lccc} 
Outcome & BT & AT & P value \\
Primary outcome & & & \\
Vaginal discharge & $2.37 \pm 0.57$ & $0.37 \pm 0.49$ & $\mathrm{p}<0.0001$ \\
LBA & $1.93 \pm 0.37$ & $0.1 \pm 0.31$ & $\mathrm{P}<0.0001$ \\
Contact bleeding & $1.27 \pm 0.83$ & $0.03 \pm 0.18$ & $\mathrm{P}<0.0001$ \\
Dyspareunia & $0.93 \pm 0.74$ & $0.03 \pm 0.18$ & $\mathrm{P}<0.0001$ \\
Secondary outcome & & & \\
Cervical erosion grading & $1.7 \pm 0.65$ & $0.47 \pm 0.58$ & $\mathrm{P}<0.0001$ \\
SF-12 & $382.73 \pm 52.33$ & $910.17 \pm 56.30$ & $\mathrm{P}<0.0001$ \\
\hline
\end{tabular}

Interpretation; significant reduction in primary and secondary outcome parameters.

\section{DISCUSSION}

The present study entitled "Efficacy of Abzan with Unani formulation in Quruhal Rahim - An open observational study" was effective in the healing of cervical erosion and relieving the symptoms. In the present study, it was demonstrated that complete healing of cervical ectopy was achieved in $56.7 \%$ of patients with mean of $1.7 \pm 0.66 \& 0.47 \pm .57 \mathrm{before}$ and after respectively. Vaginal discharge was improved in $63.3 \%$ patients with mean of $2.37 \pm 0.56$ and $0.37 \pm 0$ after treatment respectively (Table 1 and 2). While it persists in mild form in $36.7 \%$. Low backache was relieved in $90 \%$ patients, and remains $10 \%$ in mild form, with mean of $1.93 \pm 0.37$ and $0.1 \pm 0.36$ (Table 3 ). Highly significant improvement in vaginal discharge and low backache was might be due to healing of cervical ectopy, which cause relief in these symptoms. No adverse effect of research unani formulation was reported during the study.

Hence, marked improvement in outcome measures with just 3 weeks of intervention with research unani formulation as topical application was due to the effect of research drug which possess muhallilewaram, mujaffif, mudammilequruh, dafi-i-ta'ffun, qabid, musakkin, ${ }^{12,13,14,15,16,17}$ properties. Moreover, pharmacological studies shows that research drug exhibit anti microbial, anti-inflammatory, anti oxidant, anti cancer, anti ulcer, analgesic, hepato protective wound healing activities. ${ }^{13,14,18,19,20}$ Further methi, alsi, nakhoona, baboona, karamkalla contains flavonoids, saponins (glycosides), alkaloids (terpenoids, steroids) arachidonic acid, ethnol,histamine, leukotriens, polysachorides, saponins (glycosides), carbohydrates, tannins, triglisoraletc, ${ }^{13,14}$ which are considered as the active principle of anti ulcer activity. Flavonoids are group of polyphenolic compound having anti ulcerogenic, anti inflammatory, anti bacterial, antioxidants properties ${ }^{4}$ which provide strength to the mucosal barrier \& promote the ulcer to heal fast. ${ }^{21}$ The wound healing activity of unani formulation as abzan might protect against microbial invasion by providing better tissue formation. Further, the it enhance the rate of wound healing \& tissue epithelization. ${ }^{4}$

Thus, research unani formulation was effective in healing of cervical ectopy and relieving the associated symptoms. Moreover, significant improvement would be expected if duration of treatment was at least 6-8 weeks. Hence, it can be inferred that research unani formulation shows potent wound healing action, the recovery of wound might be due to the presence of chemical constituents which might favored wound healing action. Hence, it serves as an effective alternative in patients with cervical ectopy, particularly in those patients who are either not willing for cryotherapy or in whom cryotherapy is contraindicated.

This study was first of its kind; where treatment was given as abzan form which directly affects the eroded cervical area. However, small sample size, short duration of intervention, short follow up, colposcopy was not done during the study are some limitations.

\section{Future recommendation:}

- Use of research unani formulation as abzan for longer duration (6-8 weeks) on large number of patients with long follow up for better therapeutic outcome.

- To conduct RCT's with abzan of research formulation with standard treatment i.e.r electrocautery or cryo cautery.

- Future trial with use of this research formulation in patients with abnormal cervical cytology or Cervical intraepithelial neoplasia

\section{CONCLUSION}

It can be inferred that Abzan of unani formulation is effective in healing of cervical erosion and the inflammatory response due to associated cervicitis. It was found to be safe drugs when used as abzan for 21 days. Thus, the formulation may be effective and safe for the management of cervical ectopy. Hence, it serves as an effective alternative in patients with cervical erosion. 


\section{ACKNOWLEDGEMENT}

We are thankful to the Director, National Institute of Unani Medicine, India for providing all the facilities required for the completion of research work and Dr. K. P. Suresh, Biostatician and Scientist, National Institute of Veterinary Epidemiology and Disease informatics (NIVEDI) for performing the statistical analysis.

\section{Conflict of Interest: Nil}

\section{Source of Funding: Nil}

\section{REFERENCES}

1. Kumari RC, Singh BK. Role of Udumbaradi Tail in the management of a vaginal discharge due to Cervical erosion: A case report. Int J Res Ayur Pharm 2013;4(4):631-633.

2. Jindal M, Kaur S, Sharma S, Gupta KB, Pandotra P. What is better: cryocautery or electrocautery for cervical erosion? Int J Reprod Contracept Obstet Gynecol 2014; 3(3):715-719.

3. Kamini D, Meena.P. Kampillakadighrita in Garbhashaya Greeva Gata Vrana (Cervical Erosion). IJARP 2012;3(2):203-209.

4. Solanki SK, Sharma S. Role of Kshara Karma in the Management of Cervical Erosion. Ayurpharm Int J Ayur Alli Sci 2016;5(6):77-82.

5. Kartik K, Venkatesh, Uvin S. Assessing the relationship between cervical ectopy and HIV susceptibility: implications for HIV prevention in women. Am J Reprod Immunol 2013;69:68-73.

6. Yogesh M, Hetal B, Shachi P. Effect of Udumber-Sar in Garbhashaya Grivamukhagata Vrana (Cervical erosion)- A case study. IJAAR GAU J. Int J Appl Ayur Res 2017 Oct;3(4):781-784.

7. Dutta DC. Text Book of Gynecology 7th Edn. New Delhi: Jaypee Brothers Medical Publishers Ltd. 2016. Pg. 217-218.

8. Khan A. Al Akseer (Urdu trans. by Kabeeruddin). $1^{\text {sted. New }}$ Delhi: Idarae Kitabul Shifa; 2011:788-90.

9. Razi ABZ. Al Hawi Fil Tib. Vol IX. New Delhi: CCRUM; 2001:10,12,24,25,36,42,47,50,

10. Ibn Sina. Al Qanoon Fil Tib (Urdu trans. by Kantoori GH).Vol III. New Delhi: Idarae Kitabul Shifa; 2010:1092,125-126.

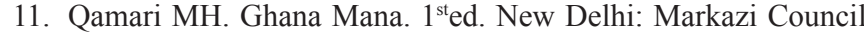
Barai Tehqeeq Tibbe Unani; 2008: 414-415.

12. Halim MA. Mufradate Azizi. New Delhi: Central Councill Research for Unani Medicine, 2009. p.49.

13. Swaroop A, Jaipuriar AS, Gupta SK, Bagchi M, Kumar P, Preuss $\mathrm{HG}$, et al. Efficacy of a novel fenugreek seed extract (Trigonellafoenum-graecum, FurocystTM) in polycystic ovary syndrome (PCOS). Int J Med Sci 2015;12(10):825.

14. Umer KH, Zeenat F, Ahmad W, Ahmad I, Khan AV. Therapeutics, phytochemistry and pharmacology of Alsi (Linumusitatissimum Linn): An important Unani drug. J Pharmacog Phytochem 2017;6(5):377-383.

15. Khan ZJ, Khan NA, Naseem I, Nami SA. Therapeutics, phytochemistry and pharmacology of Tukhm-e-Katan (Linumusitatissimum L.). Int J Adv Pharm Med Bioallied Sci 2017; 2017:1-15.

16. Rashid N, Dar PA, Ahmad HN, Rather SA. Alsi (Linum Usitatissimum (Linn.): A potential multifaceted Unani drug. J Pharmacog Phytochem 2018;7(5):3294-3300.

17. Hakim A. Tajudlin. Ahmed G. Jahan N. Evaluation of anti-infllammatory activity of the pods of iklil-ul-Malik (Astraogalushamosus. Linn). Indian J Natl Prod Reso 2010;(I):34-37.
18. Jabeen A, Khan AA, Alam T, Maaz M, Mohmad SH. J Pharmac Sci Innov 2014;3(5):401-409.

19. Umer KH, Zeenat F, Ahmed W. Khan VK. Theraputics phytochemistry and pharmacology of Iklilul Malik (Astragalus hamosus Linn) A natural unani remedy. Int J Herb Med 2017;5:1-4.

20. Khan MA. Asmaul Advia (Edited hy S. Z. Rehman). Aligarh: Publication Division. AMU: 2002:45

21. Gur CS, Onbasilar I, Atilla P, Genc R, Cakar N, Gurhan ID, et al. In vitro growth stimulatory and in vivo wound healing studies on cycloartane-type saponins of Astragalus genus. J Ethnopharmacol 2011;134: 844-850.

22. Bernard Rosner. Fundamentals of Biostatistics, $5^{\text {th }}$ Edition, Duxbury, 2000;pg 80-240.

23. Suresh KP, Chandrasekhar S. Sample Size estimation and Power analysis for Clinical research studies. J Human Reprod Sci 2012;5(1):7-13.

24. Hashmi S, Begum W, Sultana A. Efficacy of Sphaeranthusindicus and cream of Lawsoniainermis in cervical erosion with cervicitis. Eur J Integr Med 2011;3:183-185.

25. Mirza S, Naaz SA, Alim SM, Rahman A. Analgesic, anti-inflammatory and anti-microbial activities of Irsa (Irisensata): A clinical study on the patients of Iltehabe Unqur-Reham (Cervicitis). IJPPR 2015;3(4): 66-72.

26. Patil P, Sharma P. Colposcopic evaluation of cervical erosion in symptomatic women. Int J Reprod Contracept Obstet Gynecol 2017;6(6):2207-2211.

27. Latafat T, Siddiqui MMH, Jafri SAH. A Clinical study of marhamdakhlion on chronic cervicitis and cervical erosion; Ancient Sci Life 1992;11(3\&4):158-162.

28. Al-Kaseer EA. Epidemiological characteristics of women with cervical erosion in Al-Sader city, Baghdad, Iraq. J Fac Med Baghdad 2010; 52(2):157-158.

29. Cekmez Y, Sanlikan F, Gocmen A, Vural A, Turkmen SB. Is cryotherapy friend or foe for symptomatic cervical ectopy? Med Princ Prac 2016;25:8-11.

30. Shivanna BS, Shivanna L, Kulkarni P. Comparative study of efficacy of cryosurgery and Albothyl® solution in the management of cervical erosion in a rural hospital. J Dent Med Sci 2014;13(9):106-109.

31. Gautam A, Rajan S, Rajan S, Sharma E. A clinical study of Kusthadi Varti in Karnini Yonivyapada w.s.r. to cervical erosion. Int J Curr Res 2017;9(12):62140-62143.

32. Bangal VB, Patil NA, Gavhane SP, Shinde KK. Colposcopy guided management of cervical erosions in Rural population. Sch J App Med Sci 2014;2(1):261-265.

33. Koteswari M, Rao N, Renuka IV, Devi CP. A study of Pap smear examination in women complaining of leucorrhea. J Dent Med Sci 2015;14(1):37-42.

34. Zulkifle M, Ansari AAH, Shakir M, Kamal Z, Alam T. Management of non-healing leg ulcers in Unani system of medicine. Int Wound J 2012; 366-372.

35. Qadry JS. Pharmacognosy. $16^{\text {th }}$ ed. New Delhi: JS. Offset Printers; 2014: 170.

36. Ibn Rushd. Kitabul Kullyat. (Urdu trans.). New Delhi: CCRUM; 1980.pg.79-81.

37. Gupta P, Sharma S. Clinical evaluation of the efficacy of Kashara Karma with ApamargaKashara and Jyatyaditailapichu in the management of cervical erosion (Karniniyonivyavada).WJCPMT. 2015; 1(3): 43-49.

38. Monroy OL, Aguilar C, Lizano M, Talonia FC, Cruz RM, Zavaleta LR. Prevalanceof human papillomavirus genotypes and mucosal IgA anti-viral responses in women with cervical ectopy. J Clin Virol 2010;47:43-48. 
39. Anees S, Mustafa S. Clinical study for the efficacy of Unani formulation in the management of vaginal discharge associated with cervicitis (Iltehabe unqurrehm). IABCR 2017;3(4):127129.

40. Tanvir A, Izharul H, Aisha P, Nazamuddin M, Shaista P. Hulba (Trigonella foenum graecum): The common Indian spice full of medicinal values. Int J Preclin Pharmac Res 2014;5(1):41-46.

41. Idris AM. Methi (Trigonella fenum graceum): A Multifunctional Herbal Drug. JHMR. 2018,3(26):1-8.

42. Dharajiya D, Jasani H, Khatrani T, Kapuria M, Pachchigar K, Patel P. Evaluation of antibacterial and antifungal activity of fenugreek (Trigonella foenum graecum) extracts. Int J Pharm Pharm Sci 2016;8(4):212-217.

43. Miraj s, Alesaidi S. A systemic review study of the therapeutic effects of Matricaria recuitta chamomile (chamomile ). Electr Physic 2016;8(9):3024.
44. Sharma P, Sharma S, Nariyal V. A clinical study to evaluate efficacy of Snuhi Kshara and Dhatakyadi Tail Pichu in the management of Karnini Yonivyapad w.s.r. to cervical erosion. Int Ayur Med J 2016;4(9):2793-2798.

45. Hussain SM. Herbal unani Medicine all India; Unani Tibbi conference New Delhi 53

46. Kabeeruddin M. Makhzanul Mufradat. New Delhi. Aijaz publication house: 2007:74-75, 76-77, 93-94, 398-399.

47. Larson CO, Schlundt D, Patel K, Hargreaves M, Beard K. Validity of the SF-12 for use in a low-income African American community-based research initiative (REACH 2010). Prev Chronic Dis Public health Res Pract Policy 2008;5(2):01-11. 